But other stray items, even dust kitties, were not allowed. The only exceptions were friends. Stray friends abounded and were always welcome.

Organization was also one of the hallmarks of Marver's administration as well as scholarship. He had a marvelous knack for understanding complex issues and presenting them with wonderful clarity. Sometimes, these presentations went on at great length; that length was a function of his equally marvelous integrity: $\mathrm{He}$ insisted on fairly presenting all sides of an issue, even when he passionately believed in the rightness of one side. He had a sense not only of substantive justice, but also of procedural justice.

Back in the late 1960s, when the campus was in ferment over the war in Vietnam, Vice President Hubert Humphrey was scheduled to speak at the Woodrow Wilson School. Realizing that the organization of radical students, the SDS, would try to stage demonstrations against Humphrey, Marver called some of them in to work out arrangements so that they might be heard without preventing others from hearing Humphrey. The ensuing negotiations troubled Marver; for, like many groups which tend toward anarchy, the SDS had no clearly defined leadership, and no one could speak for it. After one frustrating encounter, Marver looked out his office window at the plaza and bubbling fountain down below and said wistfully: "When I was a student at Wisconsin, I was an activist, too; but we were organized." You can bet they were.

Marver and Sheva were leaders in Hadassah, B'Nai B'rith, and other Jewish organizations, but they did not wear their religion on their sleeves-only in their hearts. They were living examples of the Torah's commands to love our neighbors and to be hospitable to strangers.

One could comment at length about Marver's scholarship, his book-length analyses Regulating Business by Independent Commission (Princeton University Press, 1955); The Politics of Israel: The First Decade of Statehood (Princeton University Press, 1957); The Job of the Federal Executive (Brookings, 1958); his study for the American Political Science Association on ethics and conflict of interest; and his editorship of Volume 400 of The Annals: The Government as Regulator (1972). One could also talk more about Sheva's help in these and other publications; or the work of both of them for the community.

But I don't remember them as learned scholars or skilled executives or community leaders, but as my children's "Aunt" Sheva and "Uncle" Marver, and as my wife's and my own dear friends.

Walter F. Murphy

Princeton, $N J$

\section{Anne Meyers Cohler}

Anne Meyers Cohler died suddenly of a stroke on December 10, 1989. She was 49 years old. At the time of her death she was a lecturer in Continuing Education and The College of the University of Chicago, and had taught previously at De Paul College and Lake Forest College.

Anne Cohler had the satisfaction shortly before her death of seeing two major works of hers on Montesquieu come to print, after years of devoted study. Her analysis of Montesquieu's political philosophy is in her book, Montesquieu's Comparative Politics and the Spirit of American Constitutionalism (Lawrence, Kansas: University Press of Kansas, 1988).

As she explains, Montesquieu did not believe that a universal standard by which one may seem to judge the worth of various regimes can be the spring that makes these regimes work. Each regime has its own motive force, or spirit. To attempt to govern by a universal standard is to produce despotism. Political science, therefore, must reject abstract principles of legitimation in the manner of Hobbes and Locke. It must turn to comparative politics in which the spirit of each particular regime is preserved and the order of regimes is found in the internal principles of action which actually shape those in political life. Montesquieu thereby shows how prudence may be cultivated in modern political circumstances. Anne Cohler found that the American founders and Tocqueville understood and preserved Mon- tesquieu's well-crafted moderation.

Her other work on Montesquieu is a translation of The Spirit of the Laws, done with Basia Miller and Harold Stone, and published by Cambridge University Press in 1989. This is the first complete English translation of Montesquieu's book since Nugent's erring approximation in the 18th century, and the authors have put all those ignorant of French in their debt. For who would not want to know what Montesquieu knows, or at least what he tells? And even those who speak French will be indebted to the scholarship in this book. This monumental effort, in which more than 2,000 citations were checked, does justice to the most comprehensive modern book on politics and will serve generations as a most useful memorial to Anne Cohler's devotion.

Before her work on Montesquieu, Anne Cohler had produced an important book entitled Rousseau and Nationalism. There she showed that Rousseau was the first to describe a pre-political "nation" as the necessary material of any social contract and thus the basis of a decent, unsophisticated politics. All students of modern nationalism ought to be in her debt. Her doctoral dissertation, this book will become an enduring contribution someday when scholars stumble over it and announce a discovery. But Anne never thirsted for success; she only knew how to deserve it.

Besides these scholarly accomplishments, Anne was also a mother to two sons, Jonathan and James, and a wife to Bertram Cohler, professor of psychology at the University of Chicago. These ordinary human offices she performed with rare competence and with an intelligence and good cheer manifest to all her friends and acquaintances. Though quietly heroic like all good women, she did not feel it necessary or wise to contain her criticism of the unworthy. When the undersigned first got to know her as a graduate student at Harvard, we listened to her trenchant judgments on personalities and events with undisguised glee. With her striking red hair she was a sight to behold, but her mind and her tongue were even better. Though she came from Texas, she received her 
undergraduate degree from the University of Chicago, and Chicago was her home. How could anyone from Second City be a hick? That was her principle and we loved her for it.

Harvey C. Mansfield, Jr. Harvard University

Glen Thurow

University of Dallas

\section{J. David Greenstone}

J. David Greenstone, William M. Benton Distinguished Service Professor of Political Science at the University of Chicago, died on February 21, 1990. He was 52 years old. J. David was born in Rochester, New York, where his mother, Helen Greenstone, still lives. He was a graduate of Harvard College. $\mathrm{He}$ received an M.A. in 1960 and a Ph.D. in 1963 in political science at the University of Chicago. He joined the faculty of the University of Chicago in 1963.

His career was notable in many ways. He was an exceptional scholar who had two intellectual careers as a political scientist. His first interest was in urban labor politics. In 1968 his book Labor in American Politics was published by Alfred A. Knopf. The book was republished with a new introduction in 1977 by the University of Chicago Press. This analysis has continued to be a significant contribution to the understanding of the role of labor in the evolving politics of the twentieth century. J. David was also the author, along with his student, close friend and colleague, Paul Peterson, of Race and Authority in Urban Politics: A Study of the War on Poverty, published by Russell Sage in 1973 and republished with a new introduction in 1976 by the University of Chicago Press. Through 1977 he published a number of articles in the area of urban and interest group politics. The breadth of his interests was reflected in the topics of several of his articles, "Racial Change and Citizen Participation: The Mobilization of Low Income Communities Through Community Action," in Robert $\mathrm{H}$.

Haveman, ed., A Decade of Federal Antipoverty Programs (New York,
1977); and "Ethnicity, Class, and Discontent: The Case of the Polish Peasant Immigrants," Ethnicity, II, 1(March, 1975), pp. 1-9. In these areas he served twice as a section chair for the annual meeting of the American Political Science Association, in 1969 and 1976.

While J. David continued to be interested in the problems of urban and interest group politics, this interest was already undergoing transformation in the years 1972-75 when he was serving as chair of the department at Chicago. Finding that his time for active writing and research was diminished by the heavy demands of chairing an unusually restive department, J. David characteristically sought the most intellectually efficient way to use his time. He chose to pursue a line of development which, for the time being, would require mostly reading, a pursuit possible during the small amounts of time allotted to him by his service to the department. $\mathrm{He}$ began what was to be a long, intensive study of Wittgenstein. He saw in Wittgenstein's view of language as a form of practical reason a way in which one might come to understand some of the anomalies and persistent currents of American political thought and behavior and a means by which he could continue his lifelong commitment to understanding the criteria for membership in the American political community. The absence of formal schools of American political thought related directly to the powerful strains of practical political reason emanating from Lincoln and his predecessors made Wittgenstein's approach especially appealing to J. David.

This interest led to several articles reflecting his new direction: "Dorothea Dix and Jane Addams: From Transcendentalism to Pragmatism in American Social Reform," Social Service Review, LIII, 4, 1979; and 'Lincoln's Political Humanitarianism: Moral Reform and the Covenant Tradition in American Political Culture," Workshop on Covenant and Politics, Center for the Study of Federalism, Temple University (May, 1982). This new direction was also the focus of his contributions to the volume he edited in honor of his teacher, Grant
McConnell, Public Values and Private Power in American Politics (Chicago: University of Chicago Press, 1982). Within a very short time J. David's attention became riveted on Lincoln as the centerpiece of the development of American political thought. He began a work of major proportions on Lincoln and the various strains of the practical reason of American political thought which gave to Lincoln his place of eminence in our moral and political history. At his death, J. David was hard at work on the volume, the largest portion of which he had completed. Completion of the volume is now the responsibility of a group of colleagues and students.

J. David Greenstone's commitment to intellectual matters was matched by his commitment to the University of Chicago. From the time he entered into graduate training in 1958 until his death J. David was absent from the university for an extended time only twice: in 1963-64 as a visiting professor at Makerere University College, Kampala, Uganda, to which he remained deeply attached, and in 1970-71 as a visiting professor at Columbia University. He viewed neither of these as permanent possibilities. He had very early committed himself to the university and the community in which it existed-a community endeared to him all the more because it had nurtured his wife, Joan, and now nurtured his children, Michael and Daniel. His loyalty to the university made him an easy target for his colleagues and the administration of the university who recognized that J. David was that rare object-an intelligent, loyal individual with a capacity for creating collegiality even in barren soil. He was ingenious in this, once converting his love of basketball into a faculty fan club for the Chicago Bulls. His colleagues elected him chair of the department from 1973-75. After serving his term he continued to be recognized as the senior statesman of the department. Each succeeding chair of the department had numerous occasions to thank heaven for J. David's unstinting willingness to help in managing the department.

J. David's loyalty and commitment to the university were recognized in a 